\title{
Pengaruh Kinerja Dosen terhadap Hasil Belajar Mahasiswa pada Pembelajaran Sains Permulaan di Kelas Rendah
}

\author{
Irvin Novita Arifin $\bowtie$ \\ Pendidikan Guru Sekolah Dasar, Universitas Negeri Gorontalo \\ DOI: $10.31004 /$ obsesi.v5i1.613
}

\begin{abstract}
Abstrak
Penelitian ini bertujuan untuk mengetahui pengaruh langsung kinerja dosen terhadap hasil belajar mahasiswa pada pembelajaran sains permulaan. Menggunakan metode survey pada penelitian ini. Selanjutnya, ada dua sumber data yang akan dijaring untuk keperluan penelitian ini, yaitu data kinerja dosen yang dijaring menggunakan instrumen angket dengan lima kategori pilihan jawaban dan hasil belajar menggunakan instrumen tes dengan lima pilihan jawaban (option). Analisis data menggunakan deskriptif dan inferensial dengan pendekatan analisis jalur (path analysis). Populasi adalah seluruh mahasiswa S1.Pendidikan Guru Sekolah Dasar yang mengikuti mata kuliah pembelajaran IPA sebanyak 202 orang mahasiswa sampel adalah 130 orang mahasiswa. Hasil penelitian menemukan bahwa, Terdapat pengaruh langsung positif kinerja dosen terhadap hasil belajar mahasiswa pada pembelajaran sains permulaan. Ini menunjukkan bahwa hasil belajar pada pembelajaran sains permulaan dari mahasiswa dipengaruhi/ditentukan oleh kinerja dosen dalam pembelajaran, artinya makin tinggi kinerja dosen dalam pembelajaran maka makin tinggi pula pencapaian hasil belajar mahasiswa pada sains.

Kata Kunci: kinerja dosen; hasil belajar mahasiswa
\end{abstract}

\begin{abstract}
This study aims to determine the direct effect of lecturer performance on student learning outcomes in early science learning. Using Methods survey in this study. Furthermore, there are two sources of data that will be screened for the purposes of this study, namely lecturer performance data that is screened using a questionnaire instrument with five categories of answer choices and learning outcomes using a test instrument with five answer choices (option). Data analysis using descriptive and inferential approach path analysis(path analysis).The population was all undergraduate students. Elementary School Teacher Education who attended the Natural Sciences learning course were 202 students sampled and 130 students. The results found that there was a positive direct effect on the performance of lecturers on student learning outcomes in early science learning. This shows that learning outcomes in the beginning of science learning from students are influenced / determined by the performance of lecturers in learning, meaning that the higher the performance of lecturers in learning, the higher the achievement of student learning outcomes in science.
\end{abstract}

Keywords : lecturer performance; student learning outcomes

Copyright (c) 2019 Irvin Novita Arifin

$\triangle$ Corresponding author:

Email Address : irvinnovitaarifin@ung.ac.id (Jalan Jenderal Sudirman no.94 Kelurahan Limba U2 Kecamatan Kota Selatan Kota Gorontalo Provinsi Gorontalo 95115)

Received 23 June 2020, Accepted 4 July 2020, Published 10 July 2020 


\section{PENDAHULUAN}

Permasalahan dalam penelitian ini adalah apakah kinerja dosen berpengaruh terhadap hasil belajar mahasiswa pada pembelajaran Sains Permulaan? Kinerja dosen merupakan persepsi kemampuan dosen yang diperlukan dalam proses belajar mengajar pada pembelajaran sains permulaan baik dari kegiatan perencanaan, pelaksanaan dan kegiatan akhir (evaluasi). Semakin tinggi kinerja dosen maka mahasiswa mampu meningkatkan hasil belajarnya sains permulaan.

Hasil penelitian ini sesuai dengan pendapat Zeegers, (2004) yang menyatakan bahwa kinerja dosen adalah kemampuan untuk melakukan pekerjaan atau tugas yang dimiliki dalam menyelesaikan pekerjaan. Maksudnya adalah kinerja dosen yang merupakan faktor penentu dalam keberhasilan proses belajar mengajar. Wujud perilaku yang diharapkan yang dapat dijadikan acuan adalah kegiatan dosen dalam proses belajar mengajar yaitu bagaimana seorang dosen melakukan perencanaan sebelum proses belajar mengajar berlangsung, melaksanakan kegiatan pembelajaran, dan menilai hasil belajar Disadari proses pembelajaran tidak terlepas dari aktivitas belajar mengajar, aktivitas belajar mengajar sangat ditentukan oleh banyak faktor yaitu diantaranya faktor yang berasal dari dalam diri mahasiswa dan faktor yang berasal dari lingkungan mahasiswa berupa kinerja dosen dan hasil belajar. Kinerja dosen merupakan faktor penentu keberhasilan proses belajar mengajar diperguruan tinggi. Dosen merupakan ujung tombak keberhasilan pendidikan, karena sebagai pendidik dosen mengemban amanah untuk mengembangkan potensi yang dimiliki mahasiswa, baik dari aspek pengetahuan, keterampilan, dan sikap yang sesuai dengan tujuan yang telah ditetapkan. Proses pembelajaran tidak terlepas dari aktivitas belajar mengajar, aktivitas belajar mengajar sangat ditentukan oleh kerjasama antara dosen dan mahasiswa (Sudjana, 2009; Prasetya \& Ahmadi, 2005).

Indonesia, (2012) juga dijelaskan mengenai tujuan Pendidikan Tinggi, yaitu (1) berkembangnya potensi mahasiswa agar menjadi manusia yang beriman dan bertakwa kepada Tuhan Yang Maha Esa dan berakhlak mulia, sehat, berilmu, cakap, kreatif, mandiri, terampil, kompeten, dan berbudaya untuk kepentingan bangsa, (2) dihasilkannya lulusan yang menguasai cabang ilmu pengetahuan dan atau teknologi untuk memenuhi kepentingan nasional dan peningkatan daya saing bangsa (3) dihasilkannya ilmu pengetahuan dan teknologi melalui penelitian yang memperhatikan dan menerapkan nilai humaniora agar bermanfaat bagi kemajuan bangsa, serta kemajuan peradaban dan kesejahteraan umat manusia, dan (4) terwujudnya pengabdian masyarakat berbasis penaran dan karya penelitian yang bermanfaat dalam memajukan kesejahteraan umum dan mencerdaskan kehidupan bangsa.

Fokus utama yang diolah dan digodok dalam peningkatan sumber daya manusia diperguruan tinggi adalah mahasiswa yang merupakan pelanggan eksternal paling utama menerima jasa perguruan tinggi sebagaimana yang terdapat dalam tujuan pendidikan tinggi. Mahasiswa merupakan masyarakat kampus yaitu salah satu bagian dari kaum intelektual karena memiliki keistimewaan mengenyam pendidikan diperguruan tinggi, oleh karena itu mahasiswa dituntut memiki kualitas intelektual yang memadai, untuk mewujudkan hal tersebut dosen wajib meningkatkan kinerjanya. Menurut Salirawati, (2004) Kinerja adalah sesuatu yang dilakukan oleh seseorang sebagai profesi secara sengaja untuk mendapatkan penghasilan. Kerja juga dapat diartikan sebagai pengeluaran energi untuk kegiatan yang dibutuhkan oleh seseorang untuk mencapai tujuan. Menjadi dosen yang profesional serta berkompetensi dalam memajukan pendidikan memerlukan energi yang besar. Kinerja adalah performance atau unjuk kerja performanceis out put derives from proceses, human or therwise maksud dari kalimat tersebut, kerja adalah hasil dari suatu proses yang dilakukan manusia, August W. Smith (Rusman, 2012).

Jadi kinerja merupakan keberhasilan suatu individu atau sekelompok individu dalam menunaikan tugas dan tanggung jawabnya sehingga mencapai tujuan yang diharapkan berdasarkan standar yang telah ditetapkan. Sebaliknya jika kinerja dosen yang rendah akan 
berdampak pada rendahnya hasil belajar mahasiswa pada pembelajaran IPA sehingga tujuan pembelajaran tidak tercapai. Konsekuensi rendahnya kinerja dosen berakibat pada masalah-masalah sebagai berikut: sulitnya dosen menguasai bahan pembelajaran karena terbatasnya sarana dan prasarana, media pembelajaran, kurang mampunya dosen dalam mendiagnosis kesulitan belajar mahasiswa, kurang mampunya dosen melaksanakan proses pembelajaran berupa tidak terpenuhinya kehadiran dosen dalam memberikan kuliah, adanya kesibukan dosen dengan jabatan di dalam maupun di luar kampus, adanya kelebihan jam mengajar dosen, serta tidak mampunya dosen dalam mengevaluasi hasil belajar mahasiswa. Hal ini berindikasi pada rendahnya hasil belajar mahasiswa pada pembelajaran IPA.

Pintrich \& De Groot, (2003) Hasil belajar merupakan kemampuan (performance) yang dapat teramati dalam diri seseorang dan disebut kapabilitas, menurut Gagne, ada lima kategori kapabilitas manusia yaitu, 1) Keterampilan intelektual (intelektual skill), 2) Strategi kognitif (kognitive strategy), 3) Informasi ferbal (ferbal information), 4) Keterampilan motorik (motor skill) 5) Sikap (attitude). Menurut Susanto, (2012) yaitu perubahan-perubahan yang terjadi pada diri siswa, baik yang menyangkut aspek kognitif, afektif, dan psikomotor sebagai hasil dari kegiatan belajar berupa hasil belajar IPA di kelas awal yang difokuskan pada pengetahuan berupa aktivitas hasil belajar IPA yang meliputi perubahan-perubahan yang terjadi pada diri mahasiswa menyangkut kemampuan mahasiswa dalam menguasai materi IPA yang dapat dipraktekkan pembelajarannya di kelas awal baik yang menyangkut aspek kognitif yang meliputi materi makhluk hidup dan lingkungan berupa :(1) Ekologi (2) Saling ketergantungan antara makhluk hidup. Jadi hasil belajar yang dimaksud adalah merupakan kompotensi yang diperoleh mahasiswa sebagai akibat dari proses pembelajaran IPA di kelas awal baik perubahan kognitif, afektif, dan psikomotorik.

Faktor pendukung peningkatan hasil belajar adalah peningkatan kinerja dosen oleh karena itu perlu dirancang kegiatan perkuliahan yang dapat menginspirasi mahasiswa untuk kelak dapat melaksanakan pembelajaran IPA di kelas awal lebih optimal yang dalam hal ini dibutuhkan dukungan kinerja dosen dengan tahap awal perencanaan adalah, merancang perkuliahan yang dapat memotivasi mahasiswa, mengingat mahasiswa Pendidikan Guru Sekolah Dasar sangat beragam berasal dari latarbelakang yang berbeda baik asal sekolah, pengalaman, sikap dan kebiasaan yang berbeda-beda khususnya kemampuan akademiknya dalam bidang IPA (Fardiah, Murwani, \& Dhieni, 2019).

Harapannya hal ini mempermudah pemprosesan informasi ketika mahasiswa membangun konsep Nafiah \& Suyanto, (2014) artinya seorang mahasiswa mampu membangun konsep pembelajaran IPA di kelas awal yang tidak telepas dari karakteristik anak usia dini yang tahapan berpikirnya masih kongkrit, belajar melalui bermain, maka di perlukan perencanaan pembelajaran IPA yang dikemas dengan keterampilan mengajar guru sedemikian rupa sehingga konsep IPA dapat tersampaikan pada anak di kelas rendah 1,2,dan 3 yang didukung oleh teori-teori dan praktek-praktek belajar anak usia dini khususnya pada pembelajaran IPA di kelas awal. Dengan demikian jika perkuliahan terkait IPA dilaksanakan oleh dosen dengan memperhatikan karakteristik dan hasil belajar tersbut, maka mahasiswa dengan mudah akan mampu memproses informasi dalam rangka mengkonstruksi pengetahuannya menyangkut pembelajaran IPA di kelas awal sebab disadari dosen merupakan ujung tombak keberhasilan pembelajaran yang dalam hal ini kenerja dosen yang tinggi diharapkan dapat meningkatkan hasil belajar mahasiswa pada pembelajaran Sains Permulaan (Witarsa \& Dista, 2019; Aritonang, 2008)

Tujuan dari penelitian ini adalah untuk mengetahui pengaruh langsung kinerja dosen terhadap hasil belajar mahasiswa pada pembelajaran sains permulaan. Dalam rangka meningkatkan hasil belajar mahasiswa khususnya penguasaan materi Ilmu pengetahuan Alam yang luas dan mendalam khususnya sains permulaan di sekolah dasar yang mencakup kelas 1, 2 dan 3 yang masih tergolong anak usia dini maka, tanpa dukungan dosen yang mampu memahami cara mendidik yang baik dalam hal meningkatkan kinerja 
dosen seperti pemberian motivasi kepada mahasiswa, segala upaya peningkatan hasil belajar tidak akan mencapai hasil yang optimal.

\section{METODOLOGI}

Jenis penelitian yang digunakan adalah dalam bentuk survei, data dikumpulkan melalui mahasiswa yang terpilih sebagai anggota sampel dengan menggunakan instrumen yang disusun khusus untuk penelitian ini, metode survei yang digunakan dalam penelitian ini adalah metode survei kausal yang sifatnya menjelaskan hubungan dengan teknik analisis jalur yang dapat mengestimasi pengaruh seperangkat variabel bebas (eksogen) terhadap variabel terikat (endogen) dalam hubungan sebab akibat. Variabel dalam penelitian ini terdiri dari variabel bebas (eksogen) dan variabel terikat (endogen). Variabel eksogen kinerja dosen $(X)$ dan variabel endogen berupa hasil belajar mahasiswa pada pembelajaran sains permulaan $(\mathrm{Y})$ dapat diilustrasikan pada gambar berikut,

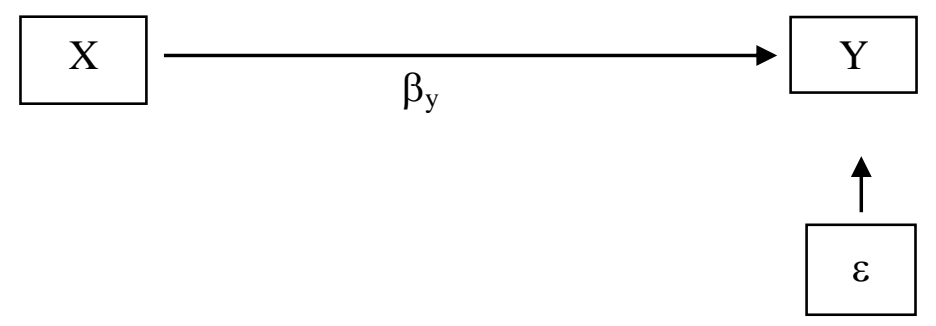

\section{Gambar 1. Variabel eksogen kinerja dosen $(X)$ dan variabel endogen berupa hasil belajar mahasiswa pada pembelajaran sains permulaan $(\mathrm{Y})$}

Populasi target dalam penelitian ini adalah mahasiswa di Jurusan Pendidikan Guru Sekolah Dasar (PGSD) Fakultas Ilmu Pendidikan Universitas Negeri Gorontalo yang duduk di semester IV sebanyak 202 orang mahasiswa yang tersebar pada 6 kelas. Teknik pengambilan sampel menggunakan teknik Multi Stage Random Sampling" Selanjutnya dan terpilih sebagai sampel melalui proses sampling dalam penelitian ini berjumlah 130 orang mahasiswa. Selanjutnya waktu penelitian dilaksanakan pada semester Genap tahun ajarn 2019/2020 selama tiga bulan yaitu Januari-Maret 2020.

Analisis data yang digunakan dalam penelitian ini terdiri atas dua bagian, yaitu analisis deskriptif dan analisis inferensial. Analisis deskriptif dilakukan dengan menyajikan data melalui tabel distribusi frekuensi, histogram, rata-rata dan simpangan baku. Sedangkan untuk analisis inferensial digunakan untuk menguji hipotesis. Analisis ini menggunakan analisis regresi dan korelasi. Sebelum melakukan pengujian hipotesis, terlebih dahulu dilakukan pengujian normalitas data ketiga variabel dengan menggunakan Liliefors. Untuk pengujian hipotesis menggunakan statistik analisis jalur.

Selanjutnya, instrumen penelitian ini terlebih dahulu dilakukan validasi oleh pakar kemudian dilakukan uji coba lapangan untuk melihat validitas butir dan reliabilitas instrumen. Untuk tes hasil belajar menghitung validitas butir soal menggunakan rumus korelasi point biserial. Berdasarkan hasil analisis dari 32 butir soal dengan taraf signifikan 0,05 ( $\mathrm{r}_{\text {tabel }}$ sebesar 0,361$)$ diperoleh 25 butir soal soal yang valid dan 7 butir soal yang tidak valid (drop). Perhitungan realibilitas instrumen dilakukan dengan menggunakan KR-20. Berdasarkan hasil perhitungan diperoleh $\mathrm{r}_{11}$ instrumen hasil belajar sebesar 0,894 dengan demikian dapat dikategorikan bahwa reabilitas tes hasil belajar memiliki tingkat kepercayaan yang tinggi. Sementara itu instrumen kinerja dosen untuk menghitung validitas butir soal menggunakan korelasi product moment dari pearson. Berdasarkan hasil analisis dari 32 butir soal dengan taraf signifikan 0,05 ( $\mathrm{r}_{\text {tabel }}$ sebesar 0,361 ) diperoleh 25 butir soal yang valid dan 5 butir soal tidak valid (drop) dan perhitungan reabilitas instrumen dilakukan dengan menggunakan rumus Alpha Cronbach. Berdasarkan hasil perhitungan diperoleh $\mathrm{r}_{11}$ 
instrumen kinerja dosen sebesar 0,912 dengan demikian dapat dikategorikan bahwa reabilitas instrumen kinerja dosen memiliki tingkat kepercayaan yang tinggi.

Selanjutnya, analisis data untuk menguji hipotesis digunakan dengan analisis deskriptif dan inferensial. Analisis deskriptif meliputi, menentukan mean, median, modus dan standar deviasi, serta memvisualisasikan data hasil penelitian dalam bentuk tabel distribusi frekuensi dan histogram. Adapun analisis inferensial berkaitan dengan hipotesis penelitian. Sebelum melakukan pengujian hipotesis, terlebih dahulu dilakukan pengujian normalitas data ketiga variabel dengan menggunakan Liliefors. Untuk pengujian hipotesis menggunakan statistik analisis jalur.

\section{HASIL DAN PEMBAHASAN}

Data hasil belajar mahasiswa pada pembelajaran sains permulaan dikumpulkan melalui tes bentuk pilihan ganda yang berjumlah 25 butir soal. Berdasarkan hasil jawaban dari 130 responden (mahasiswa) yang diperoleh melalui aplikasi google class room dan dengan menggunakan program SPSS for Window versi 23 diperoleh informasi seperti pada Tabel 1 dan Tabel 2.

Tabel 1. Memberikan informasi bahwa data disusun dalam tabel distribusi frekuensi data berkelompok dengan banyak kelas adalah 8 dan panjang interval kelas adalah 9 .

Tabel 1. Tabel Distribusi Frekuensi Data Hasil Belajar IPA di Kelas Awal

\begin{tabular}{|c|c|c|c|c|c|}
\hline \multicolumn{6}{|c|}{ Hasil Belajar Konsep Dasar IPA } \\
\hline & & Frequency & Percent & Valid Percent & $\begin{array}{c}\text { Cumulative } \\
\text { Percent }\end{array}$ \\
\hline \multirow[t]{9}{*}{ Valid } & $20-28$ & 31 & 23.8 & 23.8 & 23.8 \\
\hline & $29-37$ & 31 & 23.8 & 23.8 & 47.7 \\
\hline & $38-46$ & 19 & 14.6 & 14.6 & 62.3 \\
\hline & $47-55$ & 18 & 13.8 & 13.8 & 76.2 \\
\hline & $56-64$ & 19 & 14.6 & 14.6 & 90.8 \\
\hline & $65-73$ & 5 & 3.8 & 3.8 & 94.6 \\
\hline & $74-82$ & 5 & 3.8 & 3.8 & 98.5 \\
\hline & $83-91$ & 2 & 1.5 & 1.5 & 100.0 \\
\hline & Total & 130 & 100.0 & 100.0 & \\
\hline
\end{tabular}

Tabel 2. Statistik Data Hasil Belajar IPA di Kelas Awal Statistics

\begin{tabular}{|c|c|c|}
\hline & Hasil Belajar Konsep IPA \\
\hline $\mathrm{N}$ & Valid & 130 \\
\hline & Missing & 0 \\
\hline & & 42.80 \\
\hline & & 40.00 \\
\hline & & 32 \\
\hline & eviation & 16.036 \\
\hline & & 257.153 \\
\hline $\mathrm{Su}$ & & 5564 \\
\hline
\end{tabular}

Tabel 2 memberikan informasi tentang hasil olahan data berdasarkan tabel distribusi frekuensi. Hasil output SPSS diperoleh rata-rata (mean) sebesar 42,80; nilai tengah data (median) sebesar 40,00; modus (mode) sebesar 32; dan standar deviasi sebesar 16,04. Jika diperhatikan letak rata-rata, median, dan modus dalam kurva normal maka data hasil belajar IPA di kelas awal dari mahasiswa PGSD pada Semester Genap Tahun Pelajaran 2019/2020 cenderung rendah.

Sebaran data hasil belajar konsep dasar IPA berdasarkan tabel distribusi frekuansi seperti Gambar 1. 


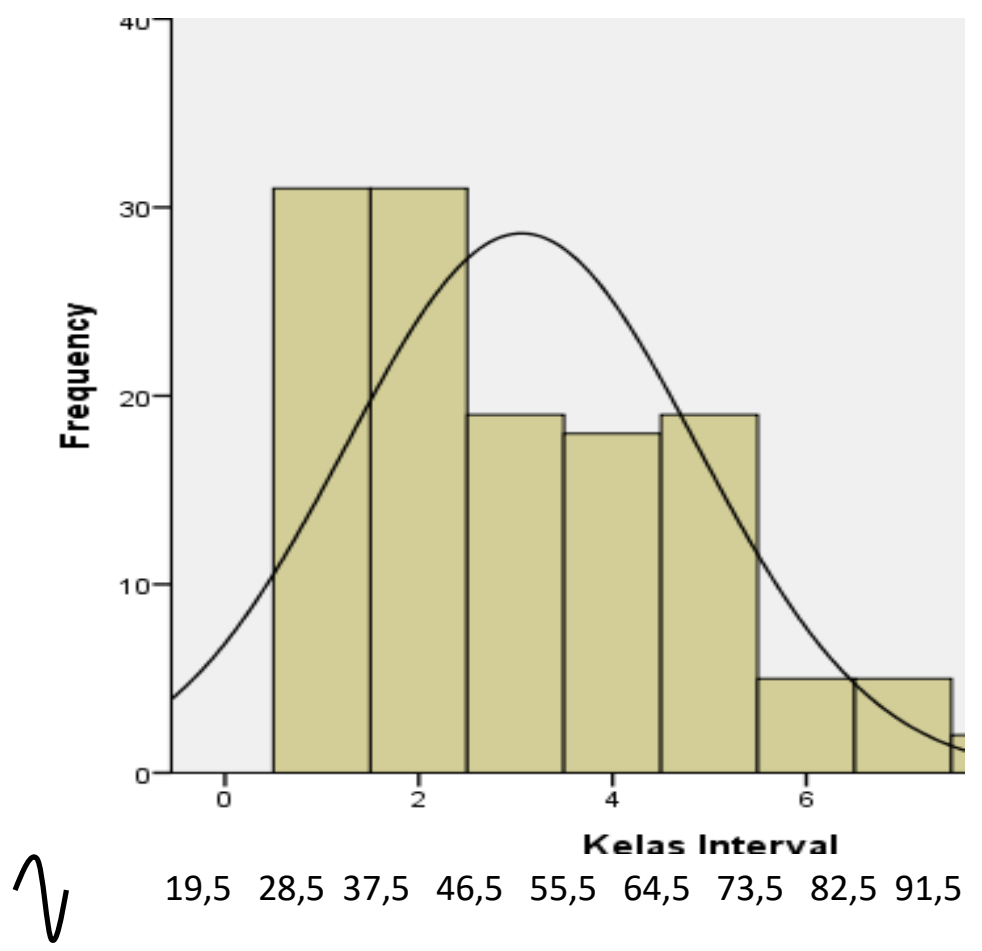

\section{Gambar 2. Histogram Hasil Belajar Konsep Dasar IPA}

\section{Kinerja Dosen}

Data kinerja dosen dikumpulkan melalui angket dengan skala lima yang berjumlah 25 butir soal. Berdasarkan hasil jawaban dari 130 responden (mahasiswa) dan dengan menggunakan program SPSS for Window Versi 23 diperoleh informasi seperti pada Tabel 3. dan Tabel 4.

Tabel 3. Tabel Distribusi Frekuensi Data Kinerja Dosen

\begin{tabular}{lrrrrr}
\hline \multicolumn{7}{c}{ Kinerja Dosen } \\
\hline \multirow{7}{*}{ Valid } & Frequency & Percent & Valid Percent & \multicolumn{2}{c}{$\begin{array}{c}\text { Cumulative } \\
\text { Percent }\end{array}$} \\
\cline { 2 - 6 } & \multicolumn{7}{c}{$37-43$} & 33 & 25.4 & 25.4 & 25.4 \\
\cline { 2 - 6 } & $44-50$ & 39 & 30.0 & 30.0 & 55.4 \\
\cline { 2 - 6 } & $51-57$ & 13 & 10.0 & 10.0 & 65.4 \\
\cline { 2 - 6 } & $58-64$ & 15 & 11.5 & 11.5 & 76.9 \\
\cline { 2 - 6 } & $64-71$ & 12 & 9.2 & 9.2 & 86.2 \\
\cline { 2 - 6 } & $72-78$ & 12 & 9.2 & 9.2 & 95.4 \\
\cline { 2 - 6 } & $79-85$ & 130 & 100.0 & 4.6 & 100.0 \\
\cline { 2 - 6 } & Total & & & 100.0 & \\
\hline
\end{tabular}

Tabel 4. Statistik Data Kinerja Dosen Statistics

\begin{tabular}{|c|c|c|}
\hline \multicolumn{3}{|c|}{$\begin{array}{ll}\text { Kinerja Dosen } \\
\end{array}$} \\
\hline \multirow[t]{2}{*}{$\mathrm{N}$} & Valid & 130 \\
\hline & Missing & 0 \\
\hline \multicolumn{2}{|c|}{ Mean } & 53.65 \\
\hline \multicolumn{2}{|c|}{ Median } & 49.50 \\
\hline \multicolumn{2}{|c|}{ Mode } & $42^{\mathrm{a}}$ \\
\hline \multicolumn{2}{|c|}{ Std. Deviation } & 12.868 \\
\hline \multicolumn{2}{|c|}{ Variance } & 165.592 \\
\hline \multicolumn{2}{|c|}{ Sum } & 6975 \\
\hline
\end{tabular}


Tabel 4 memberikan informasi bahwa data disusun ke dalam tabel distribusi frekuensi data berkelompok dengan banyak kelas dan panjang kelas interval masing-masing 7. Tabel 4 memberikan informasi tentang hasil olahan data berdasarkan tabel distribusi frekuensi. Hasil output SPSS diperoleh rata-rata (mean) sebesar 53,65; nilai tengah data (median) sebesar 49,50; modus (mode) sebesar 42; dan standar deviasi sebesar 12,87. Jika diperhatikan letak rata-rata, median, dan modus dalam kurva normal maka data kinerja dosen pada Semester Genap Tahun Pelajaran 2019/2020 cenderung rendah.

Sebaran data kinerja dosen berdasarkan tabel distribusi frekuansi seperti Gambar 2.

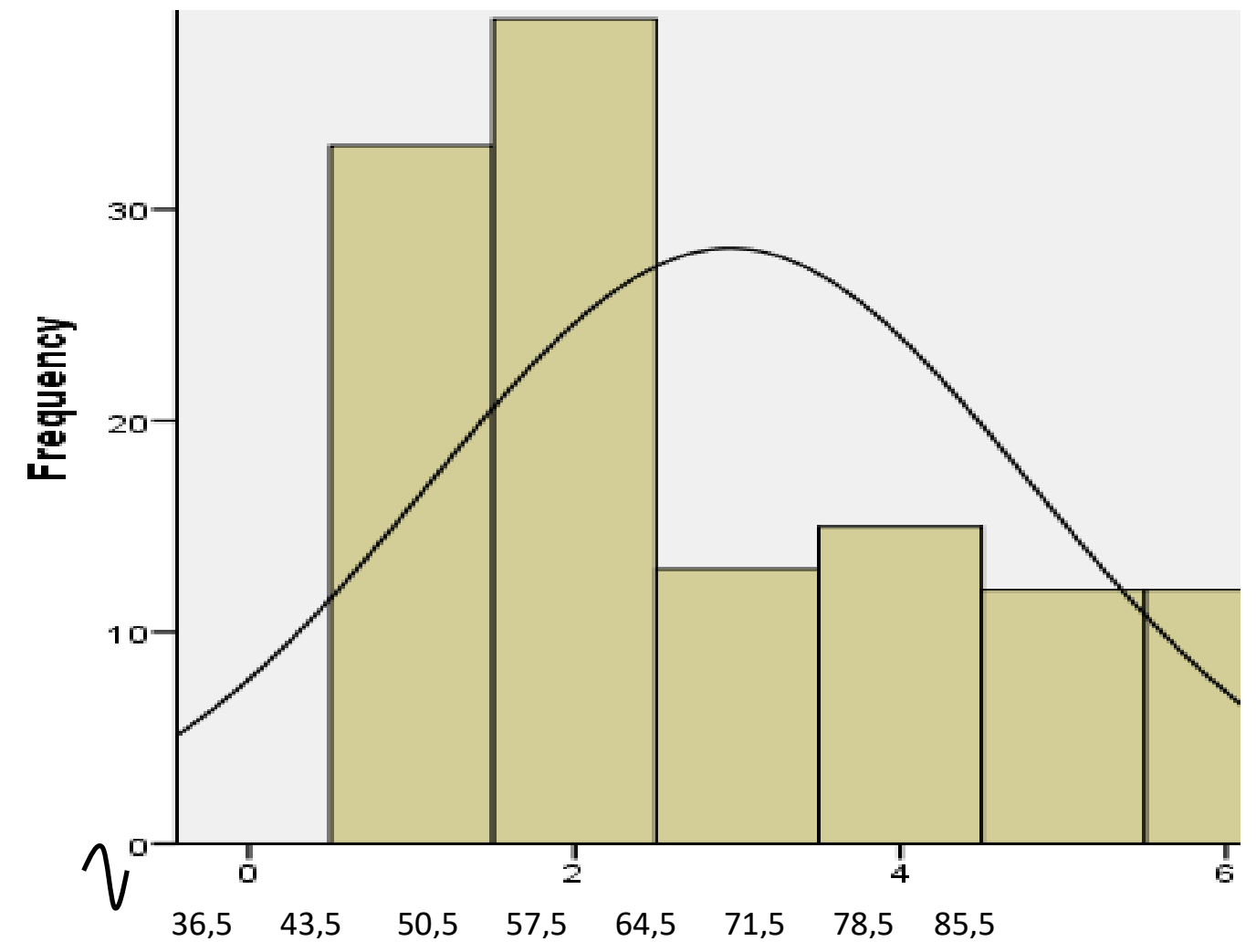

Gambar 3. Histogram Kinerja Dosen

Output hasil pengujian normalitas galat taksiran dari hasil belajar IPA di kelas awal $(\mathrm{Y})$ atas kinerja dosen $\left(\mathrm{X}_{3}\right)$ seperti pada Tabel 5

Tabel 5 Hasil Pengujian Normalitas Galat Taksiran Regresi Y atas X Menggunakan Uji Kolmogorov-Smirnov One-Sample Kolmogorov-Smirnov Test

\begin{tabular}{llr}
\hline & & Normalitas Galat taksiran Regresi Y atas X3 \\
\hline $\mathrm{N}$ & & 130 \\
\hline Normal Parameters ${ }^{\mathrm{a}, \mathrm{b}}$ & Mean & .000001 \\
\cline { 2 - 3 } & Std. Deviation & 11.6628481 \\
\hline \multirow{2}{*}{ Most Extreme Differences } & Absolute & .072 \\
\cline { 2 - 3 } & Positive & .072 \\
\cline { 2 - 3 } & Negative & -.049 \\
\hline Test Statistic & & .072 \\
\hline Asymp. Sig. (2-tailed) & & $.095^{\mathrm{c}}$ \\
\hline
\end{tabular}
a. Test distribution is Normal.
b. Calculated from data.
c. Lilliefors Significance Correction.
$\mathrm{d}$. This is a lower bound of the true significance. 
Dari Tabel 5 nilai nilai Asymp. Sig. (2-tailed) atau $p$ sebesar 0,956. Karena nilai Asymp. Sig. (2-tailed $)=0,095>0,05$ maka terima $\mathrm{H}_{0}$ yang menyatakan bahwa galat taksiran regresi hasil belajar mahasiswa pada pembelajaran sains permulaan dan kinerja dosen berdistribusi normal.

Hipotesis penelitian yang diuji adalah "terdapat pengaruh langsung positif kinerja dosen terhadap hasil belajar mahasiswa pada pembelajaran sains permulaan". Hasil pengujian menunjukkan bahwa hipotesis penelitian yang diajukan peneliti teruji kebenarannya. Ini berarti bahwa hasil belajar mahasiswa pada pembelajaran sains permulaan oleh kinerja dosen. Artinya makin bagus/baik kinerja dosen dalam melaksanakan pembelajaran, maka akan makin tinggi pula pencapaian hasil belajar mahasiswa pada pembelajaran sains

Menurut Susanto, (2012) Hasil belajar yaitu perubahan-perubahan yang terjadi pada diri siswa baik menyangkut aspek kognitif, afektif, dan psikomotor sebagai hasil dari kegiatan belajar. Perubahan tingkah laku siswa akibat proses kegiatan belajar mengajar yang berupa perubahan dalam aspek kognitif, afektif, dan psikomotor merupakan hasil belajar (Ngalim Purwanto, 2009) sedangkan kinerja dosen merupakan persepsi kemampuan dosen yang diperlukan dalam proses belajar mengajar pada pembelajaran sains permulaan baik dari kegiatan perencanaan, pelaksanaan dan kegiatan akhir (evaluasi). Semakin tinggi kinerja dosen maka mahasiswa mampu meningkatkan hasil belajarnya pada pembelajaran sains permulaan.

Hasil penelitian ini sesuai dengan pendapat Sukirno \& Siengthai, (2011)yang menyatakan bahwa kinerja dosen adalah kemampuan untuk melakukan pekerjaan atau tugas yang dimiliki dalam menyelesaikan pekerjaan. Maksudnya adalah kinerja dosen yang merupakan faktor penentu dalam keberhasilan proses belajar mengajar. Wujud perilaku yang diharapkan yang dapat dijadikan acuan adalah kegiatan dosen dalam proses belajar mengajar yaitu bagaimana seorang dosen melakukan perencanaan sebelum proses belajar mengajar berlangsung, melaksanakan kegiatan pembelajaran, dan menilai hasil belajar (Samian \& Noor, 2012) terdapat sejumlah kinerja (performance) dosen dalam melaksanakan proses belajar mengajar diantaranya Model Rob. Norris, Pada model ini ada beberapa komponen kemampuan mengajar yang perlu dimiliki oleh dosen yaitu, (a) Kualitas-kualitas personal dan profesional, (b) persiapan pengajaran (c) perumusan tujuan pengajaran (d) penampilan dosen mengajar di kelas, (e) penampilan peserta didik dalam belajar dan (f) evaluasi. Selanjutnya model Oregan menurut model ini kemampuan mengajar dikelompokkan menjadi lima bagian (a) perencanaan dan persiapan mengajar (b) kemampuan guru dalam mengajar dan kemampuan peserta didik dalam belajar (c) kemampuan mengumpulkan dan menggunakan informasi hasil belajar (d) kemampuan hubungan interpersonal dengan peserta didik (e) kemampuan hubungan dengan tanggung jawab profesional.

Berdasarkan tugas utama dosen sebagai pendidik maka yang menjadi fokus evaluasi kinerja dosen yaitu menurut (Mudjihartono et al., 2010); a) Persiapan atau perencanaan pembelajaran yang dilakukan dosen, seperti: penyusunan dan pengembangan SAP," silabus, handout perkuliahan, b) Pelaksanaan pembelajaran, anatara lain kemampuan dalam menyampaiakan materi pelajaran, penguasaan materi, penggunaan alat bantu pendidikan, manajemen kelas, pemberian tugas-tugas perkuliahan, penggunaan metode pembelajaran, c) Evaluasi hasil belajar meliputi, antara lain penetapan alat atau jenis evaluasi yang digunakan, kesesuaian penggunaan jenis evaluasi dengan tujuan pembelajaran, relevansi antara soal dengan materi perkuliahan yang disampaikan kepada mahasiswa, dan d) Kemampuan dosen dalam menjalin atau berinteraksi dengan mahasiswa, memotivasi mahasiswa, membantu mahasiswa yang mengalami masalah dalam belajar.

Keterbatasan penelitian ini adalah penelitian hanya membahas sebatas persepsi mahasiswa menyangkut kinerja dosen pada pembelajaran sains permulaan. Dengan demikian dapat dipastikan bahwa kinerja dosen sangat penting dalam proses pembelajaran 
sains di perguruan tinggi sebab hal ini sangat berimplikasi pada keberhasilan belajar mahasiswa berupa peningkatan hasil belajar mahasiswa pembelajaran sains permulaan.

\section{SIMPULAN}

Terdapat pengaruh langsung positif kinerja dosen terhadap hasil belajar mahasiswa pada pembelajaran sains permulaan. Ini menunjukkan bahwa hasil belajar mahasiswa pada pembelajaran sains permulaan dipengaruh oleh kinerja dosen dalam pembelajaran, artinya makin tinggi kinerja dosen dalam pembelajaran maka makin tinggi pula pencapaian hasil belajar mahasiswa pada pembelajaran sains permulaan.

\section{UCAPAN TERIMA KASIH}

Terimakasih kepada seluruh pihak baik Rektor Universitas Negeri Gorontalo, Dekan Fakultas Ilmu Pendidikan dan ketua jurusan Pendidikan Guru Sekolah dasar yang telah mendukung dan memberikan kesempatan kepada penulis melakukan penelitian, mahasiswa sebagai salah satu sumber informasi juga yang sangat mendukung hasil penelitian. Tak lupa juga ucapan Terima kasih Yang setinggi-tingginya kepada Jurnal Obsesi Jurnal Pendidikan Anak Usia Dini yang menjadi media bagi penulis dalam mempublish karya ini. Semoga hasil penelitian ini dapat terterima dan menambah khasanah pengetahuan serta bermanfaat khususnya bagi mahasiswa, guru dan dosen serta masyarakat umum pemerhati pendidikan pada Anak Usia Dini.

\section{DAFTAR PUSTAKA}

Aritonang, K. T. (2008). Minat dan Motivasi dalam Meningkatkan Hasil Belajar Siswa. Jurnal Pendidikan Penabur.

Fardiah, F., Murwani, S., \& Dhieni, N. (2019). Meningkatkan Kemampuan Kognitif Anak Usia Dini melalui Pembelajaran Sains. Jurnal Obsesi : Jurnal Pendidikan Anak Usia Dini. https:// doi.org/10.31004/obsesi.v4i1.254

Indonesia, P. R. (2012). Undang-Undang Republik Indonesia Nomor 12 Tahun 2012. In Undang-Undang Republik Indonesia.

Mudjihartono, P., Teknik, M., Universitas, I., Yogyakarta, A., Scorecard, B., \& Keputusan, S. P. (2010). Sistem Pendukung Keputusan Penilaian Kinerja Dosen Dengan Metode Balanced Scorecard ( Studi Kasus: Universitas Respati Yogyakarta ). Seminar Nasional Informatika 2010 (SemnasIF).

Nafiah, Y. N., \& Suyanto, W. (2014). Penerapan model problem-based learning untuk meningkatkan keterampilan berpikir kritis dan hasil belajar siswa. Jurnal Pendidikan Vokasi. https://doi.org/10.21831/jpv.v4i1.2540

Ngalim Purwanto. (2009). Prinsip-prinsip dan Teknik Evaluasi Pengajaran. In PT Remaja Rosdakarya.

Pintrich, P. R., \& De Groot, E. V. (2003). A Motivational Science Perspective on the Role of Student Motivation in Learning and Teaching Contexts. Journal of Educational Psychology. https://doi.org/10.1037/0022-0663.95.4.667

Prasetya, J. T., \& Ahmadi, A. (2005). Strategi belajar mengajar. Bandung: CV.

Rusman. (2012). Belajar dan Pembelajaran Bebasis Komputer Mengembangkan Profesionalisme Guru Abad 21. In Belajar dan Pembelajaran Bebasis Komputer Mengembangkan Profesionalisme Guru Abad 21.

Salirawati, D. (2004). Penyusunan dan Kegunaan LKS Dalam Proses Pembelajaran. Jurrnal Online. https:// doi.org/10.1021/ic034857j

Samian, Y., \& Noor, N. M. (2012). Student's Perception on Good Lecturer based on Lecturer Performance Assessment. Procedia - Social and Behavioral Sciences, 56, 783-790. https:// doi.org/10.1016/j.sbspro.2012.09.716

Sudjana, N. (2009). Penilaian Hasil Proses Belajar Mengajar. In Sinarbaru.

Sukirno, D. S., \& Siengthai, S. (2011). Does participative decision making affect lecturer 
performance in higher education? International Journal of Educational Management, 25(5), 494-508. https:// doi.org/10.1108/09513541111146387

Susanto, H. (2012). Faktor-Faktor Yang Mempengaruhi Kinerja Guru The Factors Of Affecting The Performance of The Teachers ' of State Vocational High School. Jurnal Pendidikan Vokasi,.

Witarsa, R., \& Dista, D. X. (2019). Analisis Jawaban Siswa Usia 6 sampai 8 tahun terhadap Pembelajaran Sains Kreatif. Jurnal Obsesi: Jurnal Pendidikan Anak Usia Dini. https://doi.org/10.31004/obsesi.v4i1.288

Zeegers, P. (2004). Student learning in higher education: A path analysis of academic achievement in science. Higher Education Research and Development. https:/ / doi.org/10.1080/0729436032000168487 